\title{
LKS Himpunan: Sebuah Pengembangan Matematika Integrasi
}

\author{
${ }^{1}$ Riana, ${ }^{2}$ Malik Ibrahim \\ ${ }^{1,2}$ Sistem Informasi, Universitas Nahdlatul Ulama NTB, Indonesia \\ ${ }^{1}$ riana.ununtb@gmail.com, ${ }^{2}$ malikedu.org@gmail.com
}

\begin{abstract}
INFO ARTIKEL
Riwayat Artikel:

Diterima: 20-08-2019

Disetujui: 01-10-2019

Kata Kunci:

Matematika Integrasi;

Lembar Kerja Siswa;

Teori Himpunan.

\section{ABSTRAK}

Abstrak: Tujuan penelitian ini untuk mengembangkan Lembar Kerja Siswa (LKS) Matematika Integrasi dengan nilai-nilai agama islam, menghasilkan bahan ajar terbaru pada bidang matematika untuk lebih mudah mencapai fungsi pendidikan nasional, dan memudahkan peserta didik memahami definisi, operasi, dan sifat-sifat himpunan menggunakan pendekatan nilai-nilai agama islam. Pengambangan LKS integrasi ini menggunakan model pengembangan 4-D menurut Thiagarajan, Semmel \& Semmel yang dimodifikasi yaitu (define, design, develop, and disseminate). Subjek penelitian ini adalah siswa SMP Islam Al-Ikhlasyiah Jonggat Lombok Tengah. Instrumen penelitian menggunakan tes hasil belajar berupa pilihan ganda dan angket kevalidan LKS. Hasil validasi ahli diperoleh kriteria sangat valid dengan nilai total 209, dan hasill uji kelayakan kriteria layak digunakan. Sedangkan uji kepraktisan LKS diperoleh dengan nilai total 277. Selanjutnya dilakukan uji coba lapangan yang diberikan pada siswa SMP Islam Al-Ikhlasyiah sebanyak 20 orang. Berdasarkan analisis uji coba lapangan, penelitian ini menunjukkan bahwa LKS matematika integrasi memberikan hasil positif terhadap kemampuan afektif siswa dan memahami materi himpunan.
\end{abstract}

\begin{abstract}
The purpose of this research is to develop student worksheets (LKS) Mathematics integration with Islamic religious values, produce the latest teaching materials in the field of mathematics to more easily achieve the function of national education, and facilitate participants Students understand the definition, operation, and attributes of the association using the approach of Islamic religious values. The integration of LKS uses a 4-D development model according to Thiagarajan, Semmel \& the Modified Semmel (define, design, develop, and disseminate). The subject of this research is the student of SMP Islam Al-Ikhlasyiah Jonggat Central Lombok. The research instruments use the test results in the form of double choice and the eligibility lks. The expert validation results are obtained very valid criteria with a total value of 209, and the eligibility test criteria are worth using. While LKS practicality test is obtained with a total value of 277. Furthermore, the field trials were given to the students of SMP Islam Al-Ikhlasyiah as much as 20 people. Based on the field trials analysis, the study showed that LKS mathematics integration gave positive results towards students 'affective ability and understood the set.
\end{abstract}

towards students 'affective ability and understood the set.

\author{
Keywords: \\ Integration, \\ Set Theory.
}

\section{A. LATAR BELAKANG}

Dunia pendidikan dituntut untuk membentuk watak dan peradaban peserta didik. Hal ini disampaikan dalam Undang-undang RI No. 20 tahun 2003 tentang UUSPN pasal 3 dalam (Permendikbud RI No. 20, 2016) dijelaskan bahwa "Pendidikan nasional berfungsi mengembangkan kemampuan dan membentuk watak serta peradaban bangsa yang bermartabat dalam rangka mencerdaskan kehidupan bangsa, bertujuan untuk berkembangnya potensi peserta didik agar menjadi manusia yang beriman dan bertaqwa kepada Tuhan Yang Maha Esa, berakhlak mulia, sehat, berilmu, cakap, kreatif, mandiri, dan menjadi warga negara yang demokratis serta bertanggung jawab".

Harapan di atas dapat diwujudkan melalui mata pelajaran yang diajarkan di sekolah, salah satunya adalah matematika. Pendidikan matematika di Indonesia berkembang sejalan dengan perkembangan pendidikan matematika dunia (Suryadi, 2011). Matematika merupakan salah satu mata pelajaran yang sudah dipelajari oleh siswa sejak tingkat pendidikan dasar sampai tingkat menengah 
atas. Hal ini sesuai dengan ketentuan bahwa salah satu mata pelajaran wajib yang diajarkan disekolah adalah matematika, mulai dari Sekolah Dasar (SD) hingga Sekolah Menengah Atas (SMA/SMK) (Hasbullah, 2014). Matematika juga dapat mengubah pola pikir seseorang menjadi pola pikir yang matematis, sistematis, logis, kritis dan cermat (Hidayat, 2017). Namun pada kenyataannya, matematika masih dianggap sebagai materi yang sulit dipahami bagi siswa. Sebab kebanyakan siswa menganggap matematika sebagai proses menghafal fakta-fakta dan prosedur memasukkan bilanganbilangan ke dalam rumus (Gazali, 2016).

Mata pelajaran dengan karakter materi yang padat, waktu yang singkat, ditambah materi yang sering dianggap sulit, tidak sedikit pendidik menggunakan bahan ajar untuk membantu kegiatan belajar mengajar. Bahan ajar yang digunakan oleh guru dan siswa di sekolah merupakan salah satu hal yang perlu diperbaiki dan dikembangkan dalam proses belajar mengajar (Haryonik \& Bhakti, 2018). Salah satu bahan ajar yang dapat digunakan adalah Lembar Kerja Siswa (LKS). LKS merupakan stimulus atau bimbingan guru dalam pembelajaran yang akan disajikan secara tertulis sehingga dalam penulisannya perlu memperhatikan kriteria media grafis sebagai media visual untuk menarik perhatian peserta didik (Fannie \& Rohati, 2014).

LKS dianggap memiliki materi yang lebih ringkas, dengan latihan-latihan yang dapat membuat siswa menemukan sendiri konsep, teorema, rumus dan sebagainya (Sirajuddin, 2017). LKS merupakan lembaran-lembaran yang berisikan tugas yang harus dikerjakan oleh peserta didik (Hariyanto, 2015). Dalam pembelajaran matematika, LKS banyak digunakan untuk meningkatkan aktivitas belajar peserta didik. Menurut Ernawati (2017) menyatakan bahwa LKS dapat mempermudah peserta didik untuk memahami materi yang diberikan, kaya akan tugas untuk berlatih dan melatih kemandirian belajar siswa (Ernawati, Ibrahim, \& Afiif, 2017).

Beberapa hasil penelitian yang relevan menunjukkan bahwa LKS dapat memperoleh hasil yang positif dan efek yang baik terhadap aktivitas siswa seperti

1. Penelitian pengembangan LKS Matematika berbasis konstruktivisme untuk pembelajaran materi perkalian dua matriks di kelas XII SMA, menjelaskan bahwa penilaian dari pakar konstruktivism, guru dan pemerhati matematika, LKS berbasis konstruktivisme dikategori valid, tahapan small group menggambarkan kepraktisan LKS, dan berdasarkan observasi aktivitas siswa penggunaan LKS berbasis konstruktivisme dalam kategori sangat baik (81\%), sehingga LKS memiliki potensial efek terhadap aktivitas siswa (Surmilasari, 2012);

2. Penelitian pengembangan Lembar Kerja Siswa (LKS) berbasis POE (Predict, Observe, Explain) pada materi program linear kelas XII SMA, hasil penelitian menujukkan bahwa dari hasil analisis yang dilakukan terhadap tes akhir, diperoleh $82,36 \%$ nilai siswa mencapai kriteria ketuntasan minimum. Ini artinya LKS yang dibuat telah sesuai dengan tujuan penggunaan LKS. Sehingga LKS ini bisa digunakan oleh guru matematika SMA khususnya pada pembelajaran materi program linear (Fannie \& Rohati, 2014);

3. Penelitian pengembangan LKS berbasis pendekatan kontekstual materi kegiatan ekonomi di Indonesia siswa kelas V SD. Hasil penelitian menujukkan bahwa LKS telah layak digunakan. Berdasarkan penilaian ahli materi memperoleh hasil dengan kriteria baik dan berdasarkan ahli media juga memperoleh hasil dengan kriteria baik. Berdasarkan respon guru memperoleh hasil dengan kriteria sangat baik dan berdasarkan respon siswa juga memperoleh hasil dengan kriteria sangat baik (Isnanto, 2016);

4. Penelitian pengembangan Lembar Kerja Siswa berbasis multiple intelligences pada pokok bahasan substansi genetika kelas XII IPA SMA Negeri 16 Makassar, menjelaskan bahwa uji coba kevalidan LKS yang dikembangkan berada pada kategori valid dengan nilai rata-rata semua aspek penilaian 3,22 . Siswa juga memberikan respon positif terhadap LKS yang dikembangkan dengan rata-rata 3,33. Hal ini menandakan bahwa LKS yang dikembangkan efektif digunakan dalam proses pembelajaran (Ernawati et al., 2017).

Namun demikian, konten (isi) dari LKS yang ada saat ini belum terintegrasi dengan nilai-nilai sebagaimana yang tercantum pada Undang-Undang RI No. 20 tahun 2003 di atas. Masih banyak LKS yang digunakan di sekolah hanya menyajikan materi 
pokok tanpa diintegrasikan dengan kajian-kajian ayat al-Qur'an. Oleh karena, peneliti ingin mencoba mengembangkan bahan ajar berupa LKS Matematika Integrasi pada materi himpunan. Matematika integrasi bertujuan untuk mengintegrasikan ayatayat alquran agar peserta didik menjadi manusia yang beriman, bertaqwa kepada Tuhan Yang Maha Esa, dan berakhlak mulia. Menurut Syawahid (2014) menyatakan bahwa pembelajaran matematika dapat dijadikan sebagai wahana dalam pengembangan kecerdasan emosional dan spiritual (Syawahid \& Retnawati, 2014).

Berdasarkan paparan di atas, penelitian ini bertujuan untuk mengembangkan bahan ajar matematika berupa Lembar Kerja Siswa (LKS) matematika terintegrasi pada materi himpunan siswa SMP.

\section{B. METODE PENELITIAN}

Jenis penelitian ini adalah penelitian pengembangan (Research and Development). Penelitian pengembangan adalah metode penelitian yang digunakan untuk menghasilkan produk tertentu dan menguji keefektifan produk tersebut (Sugiyono, 2013). Adapun produk yang dihasilkan pada penelitian ini Lembar Kerja Siswa (LKS) Matematika berbasis matematika integrasi pada materi himpunan kelas VII. Diagram alir penelitian tiap tahap dapat dilihat pada Gambar 1 di bawah ini.

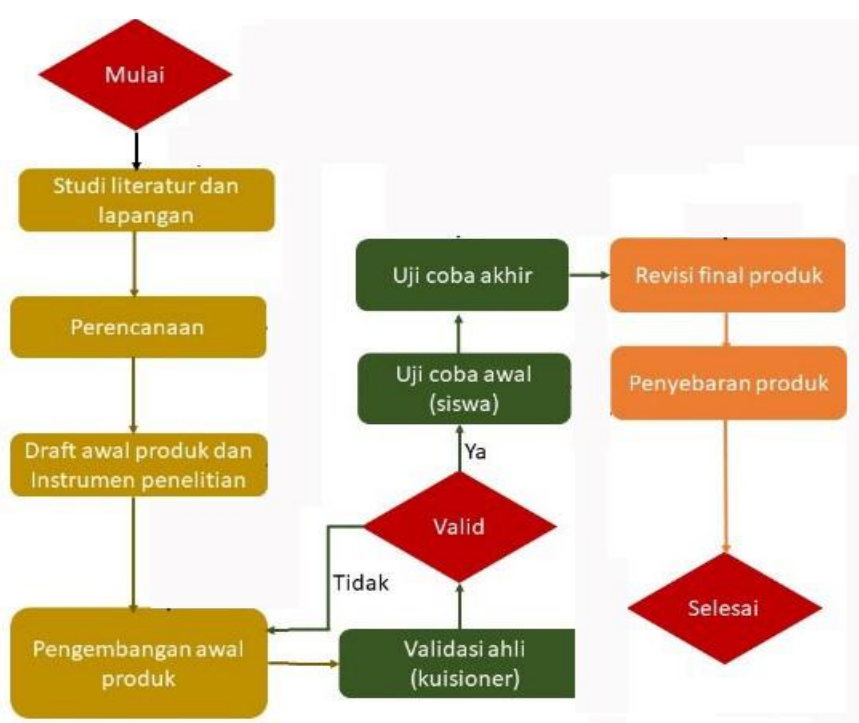

Gambar 1. Diagram Alir Penelitian

Model pengembangan (Research and Development) yang digunakan dalam penelitian ini terdiri dari 4 tahapan, yakni:

\section{Tahap Define (Pendefinisian)}

a. Analisis Awal LKS.

Sebelum melakukan pegambilan data di lapangan terlebih dahulu peneliti melakukan analisis untuk mengetahui masalah dasar dalam pengembangan LKS. Pada tahap ini dilakukan telaah LKS matematika yang sudah ada di jenjang SMP/MTs.

b. Analisis Materi.

Analisis ini dilakukan untuk mengidentifikasi, merinci dan menysusn secara sistematis materi pembelajaran yang disajikan dalam LKS. Adapun silabus materi himpunan berdasarkan (Kemdikbud, 2016) yang dituangkan dalam LKS disajikan pada Tabel 1 berikut.

Tabel 1. Silabus Materi Himpunan

\begin{tabular}{lrl}
\multicolumn{1}{c}{ Kompetensi Dasar } & \multicolumn{1}{c}{ Indikator } \\
$\begin{array}{l}\text { Menjelaskan } \\
\text { pengertian }\end{array}$ & 1. & $\begin{array}{l}\text { Membedakan himpunan } \\
\text { dan bukan himpunan }\end{array}$ \\
$\begin{array}{l}\text { himpunan, } \\
\text { himpunan bagian, } \\
\text { komplemen } \\
\text { himpunan, operasi } \\
\text { himpunan dan } \\
\text { menunjukkan } \\
\text { contoh dan bukan } \\
\text { contoh }\end{array}$ & 2. & $\begin{array}{l}\text { Menyebutkan macam- } \\
\text { macam himpunan } \\
\text { Menentukan }\end{array}$ \\
& $\begin{array}{l}\text { unsur/anggota } \\
\text { himpunan, himpunan } \\
\text { bagian dan operasi } \\
\text { himpunan }\end{array}$ \\
&
\end{tabular}

\section{Tahap Design (Perancangan )}

Kegiatan ini adalah proses merancang kegiatan pembelajaran yang disajikan dalam LKS dan tes hasil belajar. Rancangan ini disebut Draft 1.

\section{Tahap Develop (Pengembangan)}

a. Validasi Ahli

Kegiatan ini dilakukan untuk mendapatkan penguatan dari ahli terhadap LKS yang dikembangkan. Kegiatan yang diakukan adalah uji validitas terhadap desain dan materi oleh ahli bidang pembelajaran matematika. Adapun rumus yang digunakan dalam analisis data validitas produk yang dikembangkan sebagai berikut.

$$
\overline{\boldsymbol{X}}=\frac{\sum_{i=1}^{n} s_{i}}{n}
$$

Dimana $\bar{X}$ adalah nilai rata-rata hasil penilaian validator, $S_{i}$ adalah Skor rata-rata hasil penilaian validator ke-i dan $n$ adalah jumlah validator. Hasil skor rata-rata dari validator ataupun secara keseluruhan ditentukan kategori berdasarkan Tabel 2 berikut. 
Table 2. Kriteria Interval Validitas LKS

\begin{tabular}{ll}
\hline \multicolumn{1}{c}{ Interval } & \multicolumn{1}{c}{ Kategori } \\
\hline$\overline{\boldsymbol{X}}>176$ & Sangat valid \\
\hline $147<\overline{\boldsymbol{X}} \leq 176$ & Valid \\
\hline $117<\overline{\boldsymbol{X}} \leq 147$ & Cukup Valid \\
\hline $88<\overline{\boldsymbol{X}} \leq 117$ & Kurang Valid \\
\hline$\overline{\boldsymbol{X}} \leq 88$ & Tidak Valid \\
\hline
\end{tabular}

LKS matematika terintegrasi yang dihasilkan dikatakan valid jika minimal tingkat validitas yang dicapai adalah kategori valid (Syawahid, 2013). Selanjutnya peneliti melakukan uji coba awal (terbatas) kepada beberapa siswa dan pada akhir dari tahap ini dilakukan revisi jika ada masukan dari guru matematika di sekolah tersebut.

\section{b. Uji Kepraktisan LKS}

Penentuan kepraktisan pengembangan LKS dilihat dari konsistensi hasil penilaian guru terhadap LKS dan penilaian positif siswa terhadap proses pembelajaran. Adapun interval kriteria kepraktisan LKS disajikan pada Tabel 3 berikut.

Table 3. Kriteria Interval Kepraktisan LKS

\begin{tabular}{cl}
\hline Interval & \multicolumn{1}{c}{ Kategori } \\
\hline$\overline{\boldsymbol{X}}>256$ & Sangat mudah digunakan \\
\hline $213<\overline{\boldsymbol{X}} \leq 256$ & Mudah digunakan \\
\hline $170<\overline{\boldsymbol{X}} \leq 213$ & Cukup mudah digunakan \\
\hline $128<\overline{\boldsymbol{X}} \leq 170$ & Sulit digunakan \\
\hline$\overline{\boldsymbol{X}} \leq 128$ & Sangat Sulit digunakan \\
\hline
\end{tabular}

c. Analisis Data Validasi Ahli

Kegiatan ini dilakukan setelah mendapatkan hasil validasi oleh ahli, kemudian dilakukan analisis untuk mendapatkan ketentuan validitas LKS, jika belum terpenuhi maka dilakukan revisi. LKS yang telah direvisi disebut Darft 2 .

\section{d. Uji Coba Terbatas}

Kegiatan ini adalah tahapan untuk mengetahui keterbacaan kalimat dalam LKS. Uji coba terbatas dilakukan pada 1 orang guru matematika dan 10 siswa MTs Nurul Ihsan Sukarara yang memiliki kemampuan tinggi, sedang, dan rendah.

\section{e. Uji Coba Lapangan}

Kegiatan ini adalah tahapan uji coba pada objek yang lebih luas. Uji coba lapangan dilakukan untuk mengetahui kualitas perangkat pembelajaran matematika yang dihasilkan dilihat dari segi kepraktisannya. Uji coba lapangan dilakukan pada 20 siswa SMP Islam Al-Ikhlasyiah. Pada tahap ini dilakukan pembelajaran dengan menggunakan LKS matematika teritegrasi berupa Draft 3.

\section{HASIL DAN PEMBAHASAN}

Sesuai dengan tujuan penelitian ini yaitu menghasilkan LKS matematika yang terintegrasi maka berikut ini dideskripsikan hasil penelitian pada setiap tahap pengembangan beserta analisis masingmasing.

\section{Hasil Validasi Ahli}

Tahap ini berkaitan dengan hasil validasi produk yang didesain sebelumnya dan proses serta analisis hasil uji coba produk yang dikembangkan.

\section{a. Hasil Kelayakan Instrumen}

Tahap awal adalah melakukan uji kelayakan instrumen penelitian kepada dua pakar. Adapun hasil uji kelayakan diperoleh bahwa instrumen layak digunakan untuk pengambilan data penelitian. Selanjutnya, melakukan validasi ahli terhadap produk yang dikembangkan.

b. Hasil Validasi Ahli

Validasi ini dilakukan setelah desain LKS selesai. Validasi ahli dilakukan untuk mendapatkan saran dan masukan terkait konten/isi materi yakni dari ahli matematika dan ahli agama islam serta aspek tampilan penyajian LKS. Adapun hasil validasi dengan dua ahli diperoleh informasi sesuai Tabel 4 di bawah ini.

Tabel 4. Nilai Hasil Validasi

\begin{tabular}{lccc}
\hline \multirow{2}{*}{ Aspek Penilaian } & \multicolumn{2}{c}{ Skor Validator } & \\
\cline { 2 - 3 } & $\mathbf{1}$ & $\mathbf{2}$ & \\
\hline Kelayakan Materi/isi & 28 & 28 & 56 \\
\hline Kesesuaian Penyajian & 47 & 50 & 97 \\
\hline Kesesuaian Bahasa & 19 & 19 & 38 \\
\hline $\begin{array}{l}\text { Pengembangan } \\
\text { Matematika Integrasi }\end{array}$ & 9 & 9 & 18 \\
\hline \multicolumn{1}{c}{ Total } & $\mathbf{1 0 3}$ & $\mathbf{1 0 6}$ & $\mathbf{2 0 9}$ \\
\hline
\end{tabular}

Berdasarkan Tabel 4 di atas, diperoleh hasil penialaian ahli adalah 209 yang brarti "Sangat Valid" (rujukan Tabel 2). Namun ada beberapa masukan dan saran dari validator yang direvisi.

\section{Hasil Uji Coba Terbatas}

Perangkat pembelajaran yang sudah divalidasi dan menghasilkan Draft 2 selanjutnya diuji cobakan. Uji coba pertama yang dilakukan adalah uji coba terbatas. Uji coba terbatas dilakukan untuk mengetahui keterbacaan perangkat di mana 1 guru menilai dan memberikan masukan terhadap desain dan konten materi LKS dan 10 orang siswa yang mewakili kelompok dengan kemampuan tinggi, sedang dan kurang menilai keterbacaan LKS.

Data kepraktisan diperoleh dari data angket kepraktisan menurut guru dan siswa. Adapun hasil uji kepraktisan disajikan pada Tabel 5 berikut. 
Tabel 5. Skor Hasil Kepraktisan LKS Skala Kecil

\begin{tabular}{llc}
\hline No & \multicolumn{1}{c}{ Aspek } & Skor \\
\hline 1 & Kejelasan Isi & 35 \\
\hline 2 & Kemenarikan Tampilan & 35 \\
\hline 3 & Kemudahan Penggunaan & 35 \\
\hline 4 & Kemudahan Bahasa untuk & 35 \\
& Dimengerti & \\
\hline 5 & Kejelasan Informasi & 34 \\
\hline 6 & Kesesuaian dengan K13 & 33 \\
\hline 7 & Kebenaran Isi Materi & 35 \\
\hline 8 & Kebergunaan untuk Pembelajaran & 35 \\
\hline & Total & 277 \\
\hline
\end{tabular}

Berdasarkan Tabel 5 di atas, terlihat bahwa skor total sebesar 277 yang telah mencapai kriteria "sangat mudah digunakan" sehingga perangkat pembelajaran sudah bisa dikatakan praktis. Data yang dihasilkan dalam uji coba terbatas ini berupa masukan dan saran dari guru yang menilai LKS serta masukan dan saran dari siswa yang menilai keterbacaan LKS. Dari masukan dan saran dari guru dan siswa tersebut selanjutnya dijadikan dasar untuk dilakukan revisi terhadap LKS. Hasil revisi tersebut akan menghasilkan Draft 3.

Selanjutnya berdasarkan hasil uji keefektifan diperoleh bahwa persentase siswa yang mendapat nilai di atas atau sama dengan KKM sebanyak 16 siswa adalah $80 \%$. Siswa tuntas dalam memahami materi yang terkandung dalam LKS, hal ini berarti LKS efektif.

\section{Hasil Uji Coba Lapangan}

Berdasarkan hasil uji coba terbatas berupa Draft 3 selanjutnya diuji cobakan dengan skala yang lebih luas yaitu uji coba lapangan. Uji coba lapangan ini dilaksanakan pada 20 siswa kelas VII SMP Islam AlIkhlasyiah. Uji coba lapangan dilakukan untuk memperoleh data kepraktisan dan keefektifan LKS. Data hasil uji coba lapangan tersebut selanjutnya dijadikan dasar untuk dilakukan revisi perangkat pembelajaran. Hasil revisi tersebut menghasilkan Draft 4. Adapun hasil uji lapangan skala besar sesuai Tabel 6 berikut.

Tabel 6. Skor Hasil Kepraktisan LKS Skala Luas

\begin{tabular}{llc}
\hline No & \multicolumn{1}{c}{ Aspek } & Skor \\
\hline 1 & Kejelasan Isi & 36 \\
\hline 2 & Kemenarikan Tampilan & 35 \\
\hline 3 & Kemudahan Penggunaan & 35 \\
\hline 4 & $\begin{array}{l}\text { Kemudahan Bahasa untuk } \\
\text { Dimengerti }\end{array}$ & 36 \\
\hline 5 & Kejelasan Informasi & 35 \\
\hline 6 & Kesesuaian dengan K13 & 33 \\
\hline 7 & Kebenaran Isi Materi & 35 \\
\hline 8 & Kebergunaan untuk Pembelajaran & 35 \\
\hline & Total & 280 \\
\hline
\end{tabular}

Berdasarkan Tabel 6 di atas, terlihat bahwa skor total sebesar 280 yang telah mencapai kriteria "sangat mudah digunakan" sehingga perangkat pembelajaran sudah bisa dikatakan praktis. Sedangkan hasil uji keefektifan diperoleh diperoleh bahwa persentase siswa yang mendapat nilai di atas atau sama dengan KKM sebesar 65 sebanyak 17 siswa adalah 85\%. siswa tuntas dalam memahami materi yang terkandung dalam LKS, hal ini berarti LKS efektif digunakan dalam pembelajaran materi himpunan di kelas VII SMP/MTs.

\section{Revisi Produk}

Berdasarkan penilaian yang diberikan oleh ahli/praktisi dan data yang didapatkan pada tahapan uji coba, LKS yang dikembangkan telah dinyatakan memenuhi kriteria kevalidan dan kepraktisan berdasarkan kriteria penilaian yang telah ditetapkan. Sehingga Draft awal yang telah disusun dapat dinyatakan sebagai produk akhir. Akan tetapi diperlukan beberapa revisi berdasarkan masukan secara deskriptif yang diberikan oleh ahli/praktisi.

\section{a. Revisi Draft 1}

Berdasarkan saran dan masukan dari validator terhadap LKS Draft 1, maka dilakukan revisi untuk menghasilkan LKS yang valid. Berikut revisi dari perangkat pembelajaran Draft 1. Berdasarkan masukan dari validator baik secara lisan maupun tulisan pada lembar validasi, terdapat beberapa revisi yang harus dilakukan, yaitu (1) perbaikan penulisan yang keliru, penambahan konten/isi ayat alqur'an, pada LKS 1 diperjelas gambar dan kata "kunpulan" diganti menjadi "kumpulan", pada LKS 2 mengganti kata "menyebutkan" dengan kata "menyajikan", pada LKS 3 ditambahkan keterangan keterangan gambar dan perjelas warna gambar, pada LKS 5 menambahkan kegiatan mengamati siswa.

\section{b. Revisi Draft 2}

Berdasarkan hasil uji coba terbatas dengan menggunakan LKS Draft 2, maka dilakukan revisi untuk menghasilkan perangkat pembelajaran Draft 3 yang akan digunakan pada uji coba lapangan. Berikut hasil revisi Draft 2. Berdasarkan masukan dari siswa baik secara lisan maupun tulisan, terdapat beberapa revisi yang harus dilakukan, diantaranya (1) perbaikan penulisan yang keliru, (1) tampilan gambar yang kurang menarik dan perlu diberi warna, diberi penjelasan untuk istilah-istilah yang tidak dimengerti siswa seperti kata enumerasi, melata dan sebagainya.

\section{c. Revisi Draft 3}

Berdasarkan hasil uji coba lapangan, diperoleh bahwa perangkat pembelajaran matematika yang telah dihasilkan sudah memenuhi kriteria praktis. Akan tetapi, berdasarkan hasil pengamatan di lapangan, dilakukan revisi-revisi dari produk yang sudah ada guna menghasilkan produk akhir LKS 
matematika integrasi yang benar-benar mendukung pembelajaran matematika di lapangan. Secara keseluruhan LKS yang digunakan cukup dapat digunakan dan dinilai positif oleh siswa. Revisi hanya dilakukan terhadap sejumlah penulisan yang ukuran hurufnya perlu diperbesar.

\section{SIMPULAN DAN SARAN}

Hasil produk akhir yang dikembangkan berupa LKS matematika integrasi mendapatkan penguatan sangat valid oleh ahli dan dilaksanakan sesuai dengan prosedur pengembangan perangkat pembelajaran Model 4-D menurut Thiangarajan, Semmel dan Semmel yang sudah dimodifikasi. Adapun simpulan pelaksanaan penelitian yakni (1) bahan ajar yang dikembangkan berupa LKS matematika integrasi layak digunakan berdasarkan hasil uji kelayakan dari validator ahli; (2) LKS yang dikembangkan sudah memenuhi kriteria praktis untuk digunakan berdasarkan hasil uji kepraktisan LKS dengan nilai sebesar 277 dari validator ahli; dan (3) hasil uji coba lapangan yang dilakukan pada 20 siswa kelas VII SMP Islam Al-Ikhlasyiah memperoleh hasil LKS praktis dan efektif.

Saran kepada peneliti berikutnya untuk melanjutkan pengembangan perangkat pembelajaran matematika terintegrasi pada materi matematika yang lebih luas.

\section{UCAPAN TERIMA KASIH}

Tim peneliti mengucapkan terima kasih kepada (1) DRPM Kemenristekdikti RI yang telah mendanai pelaksanaan penelitian ini melalui Skim Penelitian Dosen Pemula (PDP); (2) pihak MTs. Nurul Ihsan dan SMP Islam Al-Ikhlasyiah yang telah banyak membantu kegiatan penelitian ini selama proses uji coba lapangan sehingga menghasilkan produk yang layak digunakan meskipun masih banyak kekurangan yang perlu diperbaiki kembali; dan (3) pihak LPPM Uiversitas Nahdlatul Ulama NTB yang telah memfasilitasi sehingga kegiatan ini terlaksana dengan baik.

\section{REFERENSI}

Ernawati, A., Ibrahim, M. M., \& Afiif, A. (2017). Pengembangan Lembar Kerja Siswa Berbasis Multiple Intelligences Pada Pokok Bahasan Substansi Genetika Kelas Xii IPA SMA Negeri 16 Makassar. Jurnal Biotek, 5(2), 1-18.
Fannie, R. ., \& Rohati. (2014). Pengembangan Lembar Kerja Siswa (LKS) Berbasis POE (Predict, Observe, Explain) Pada Materi Program Linier. Jurnal Sainmatika, 8(1), 96-109.

Gazali, R. Y. (2016). Pengembangan Bahan Ajar Matematika untuk Siswa SMP Berdasarkan Teori Belajar Ausubel Development of Mathematics Teaching Material for Junior High School Students Based on Ausubel Learning Theory. PYTHAGORAS: Jurnal Pendidikan Matematika, 11(2), 182-192.

Hariyanto. (2015). Implementasi Belajar dan Pembelajaran. Bandung: PT Remaja Rosdakarya.

Haryonik, Y., \& Bhakti, Y. B. (2018). Pengembangan Bahan Ajar Lembar Kerja Siswa Dengan Pendekatan Matematika Realistik. MaPan, 6(1), 40-55. https://doi.org/10.24252/mapan.2018v6n1a5

Hasbullah. (2014). Media Pembelajaran Matematika. Jakarta: Savitra College.

Hidayat, A. (2017). Problem Solving Untuk Memfasilitasi Kemampuan. Journal Cendekia, 1(2), 51-63.

Isnanto, D. (2016). Pengembangan Lks Berbasis Pendekatan Kontekstual Materi Developing Students Worksheets Based on the Contextual Approch for. Jurnal Pendidikan Guru Sekolah Dasar Edisi 32 Tahun Ke-5 2016, 5(32), 15-24.

Kemdikbud. (2016). Silabus Mata Pelajaran Sekolah Menengah Atas/Madrasah Aliyah/Sekolah Menengah Kejuruan/Madrasah Aliyah Kejuruan (Sma/Ma/Smk/Mak) Mata. In Silabus.

Permendikbud RI No. 20. (2016). Standar Kompetensi Lulusan Pendidikan Dasar dan Menengah. In Lampiran Peraturan Menteri Pendidikan dan Kebudayaan Republik Indonesia Nomor 20 Tahun 2016.

Sirajuddin, S. (2017). Pengembangan Perangkat Pembelajaran Matematika Dengan Kombinasi Pendekatan Matematika Realistik Dan Scientific Pada Siswa Kelas VII SMP. JTAM / Jurnal Teori Dan Aplikasi Matematika, 1(1), 60. https://doi.org/10.31764/jtam.v1i1.316

Sugiyono. (2013). Metode Penelitian Pendidikan Pendekatan Kuantitaif, Kualitatif, dan R\&D. Bandung; Alfabeta. https://doi.org/10.1007/s13398-0140173-7.2

Surmilasari, N. (2012). Pengembangan Lks Matematika Berbasis Perkalian Dua Matriks Di Kelas XII SMA. Thesis, Universitas Negeri Yogyakarta.

Suryadi, D. (2011). Pembelajaran Matematika. In Universitas Pendidikan Indonesia. https://doi.org/10.1371/journal.pone.0045739

Syawahid, M. (2013). Pengembangan Perangkat Pembelajaran Matematika Terintegrasi Dengan Pengembangan Kecerdasan Emosional Dan Spiritual Pada Siswa SMP/MTs Kelas VIII. Thesis, Universitas Negeri Yogyakarta.

Syawahid, M., \& Retnawati, H. (2014). Pengembangan Perangkat Pembelajaran Matematika Terintegrasi Dengan Pengembangan Kecerdasan Emosional Dan Spiritual. Jurnal Riset Pendidikan Matematika, 1(1), 12. https://doi.org/10.21831/jrpm.v1i1.2654 